\title{
Issues and Challenges of Institutionalized Old Age: \\ Case Study Report
}

\author{
Dr. L. Umadevi ${ }^{1}$, V. Kavitha Kiran ${ }^{2}$
}

\section{ABSTRACT}

Case study method was employed to study the issues and challenges of older women in old age homes. The study reveals that most of respondents were having average physical health condition. The results of study further reveal that they have less satisfaction with life, they display negative emotions like depression, lonliness.

Keywords: Old Age, Case study, well being, Physical development,

Aging is a series of processes that begin with life and continue throughout the life cycle. It represents the closing period in the lifespan, a time when the individual looks back on life, lives on past accomplishments and begins to finish off his life course. Adjusting to the changes that accompany old age requires that an individual is flexible and develops new coping skills to adapt to the changes that are common to this time in their lives (Warnick, 1995).

The definition of 'health' with regard to old age is a subject of debate. There is consensus that health in old age cannot meaningfully be defined as the absence of disease because the prevalence of diagnosable disorders in elderly populations is high. Instead, health is considered to be multifaceted: The diagnosis of disease should be complemented by assessment of discomfort associated with symptoms (e.g., pain), life threat, treatment consequences (e.g., side effects of medication), functional capacity and subjective health evaluations (Borchelt et al., 1999). Furthermore, Rowe \& Khan (1987) suggested that the health of subgroups of older adults be defined in terms of their status relative to age and cohort norms.

\section{METHDOLOGY:}

Hyderabad was selected as locale for the present study of Issues and challenges of old age. Eight old age women in age group of 65-80 years residing in old age homes were randomly selected. To study their status different scales like the elderly motivational scale, depression scale, loneliness and life satisfaction scale was administered to them. For the present study case study

\footnotetext{
${ }^{1}$ Professor, Department of Human development and family studies, College of home science, Hyderabad

${ }^{2}$ Research Associate, Department of Human development and family studies, College of home science, Hyderabad

(C) 2015 I Umadevi, K Kiran; licensee IJIP. This is an Open Access Research distributed under the terms of the Creative Commons Attribution License (http://creativecommons.org/licenses/by/2.0), which permits unrestricted use, distribution, and reproduction in any Medium, provided the original work is properly cited.
} 
method was adopted, so that each case can be studied in detail and useful data can be collected through observation.

\section{OBJECTIVE}

The objective of present study is to study the general profile of respondents, their health conditions.

To study the life satisfaction, motivation, depression and loneliness of women in old age homes

\section{CASE STUDY 1}

A case study was conducted on Mrs. Sushilagovindal 62 yrs residing at secunderabad. She belongs to karimnagar, her husband got retired as general manager of small scale industries. She has two children. It has been 25 yrs that she was detected of uterus cancer and now it has been cured. Now she is a chronic patient of high blood pressure, diabetics, hyperthyroid .she goes on weekly checkups for her side effects which were caused due to cancer treatment she thanks god for giving her supportive husband and parents who had then stood next to her all through the treatments the doctors had declared that she would survive for a month but her will power and zeal to live for the family has given her the strength to fight against the disease. Now she has no regrets about the disease or does not get depressed thinking about any such traces the family immediately stands next to her and helps in bringing her out of it she stays with her daughter for the only reason that there are better medical facilities in the city than the place where she belongs to.

She is a very active person interacts with the entire neighborhood she has lots of friends of her age group her favorite past time is to talk to people, spending time at the temples. A very joyous person makes friends easily. Her other past time activities apart from doing small house hold chores are watching TV mainly comedy shows and she keeps the track of event and incident occurring in and around the world. She reads news paper daily. Apart from keeping herself busy with all these activities she keeps herself busy with small household chores so that she doesn't fall into the trap of anxiety and depression.

The respondent was studied for different aspects of life using four different scales.

The participant had very patiently answered all the scales and also gave the explanation as how does she perceive her life. This positive attitude keeps her busy and increases her confident levels and she says she is a satisfied person ,yes she admits that she had compromised on few desires in her life and this was mainly because of her illness but now she has no regrets that she wasn't able to do them.

Motivational scale results interpreted that she has high motivation. Questions related to health were answered in "do it for my own good”. Similarity for other questions related to biological needs, relationships the reply was "do it for my pleasure ”. Geriatric Depression Scale results 
indicated a low score which implies she isn't depressed about anything in her life. After huge incidents happening in her life, the confidence that has given her the power to face any challenges.

UCLA Loneliness Scale showed that she never felt that she is alone, relationships are just superficial, in fact she believes that whoever are associated with her are her near and dears. Even if she felt depressed or lonely for a minute she watched comedy shows or news on the television which help her to get distracted from those negative thoughts.

Satisfaction with Life Scale scored interpreted that she is slightly satisfied. There must be a unconscious mind which might keep triggering the past experiences, for which she might be feeling little dissatisfied about her life but the present positive things she recover herself.

\section{CASE STUDY 2}

Lakshmamma 80 yrs: An illiterate old women residing in Secunderabad with her six children and hughi.e 11 grand children. She has wrinkled skin with white hair and actively finishes her personal work. Muscle loss can be seen .Bone density decreased but is at good health condition. But she has leg pain because of aging.

\section{Psychological well being}

She feels isolated because of staying away from her children. She wants to stay with her family members. She can't identify the names. She is very calm and quite. She mingles with anyone.

\section{Physical development}

\begin{tabular}{|l|l|l|}
\hline Vision & Hearing & smell \\
\hline $\begin{array}{l}\text { She is not having good vision. } \\
\text { She has specs }\end{array}$ & $\begin{array}{l}\text { She can hear clearly. But } \\
\text { When we will impose the } \\
\text { question she replies very } \\
\text { slowly. She will not talk } \\
\text { loudly }\end{array}$ & $\begin{array}{l}\text { She doesn't have any problem } \\
\text { in sensing the smell. }\end{array}$ \\
\hline Touch & Taste & \\
\hline $\begin{array}{l}\text { She can easily feel pain when } \\
\text { she will walk on the rough } \\
\text { area. } \\
\begin{array}{l}\text { She can easily identify objects } \\
\text { through touch. }\end{array}\end{array}$ & $\begin{array}{l}\text { She eats all type of food which is healthy and } \\
\text { tasty. }\end{array}$ & \\
\hline
\end{tabular}

\section{Cognitive development}

She has good memory capacity. She can easily remember the places of objects where she has placed before. Actively Participate in all the works. Especially in vegetable cutting, cooking. 
She can keep her bed and cupboard very neatly. And she will try to make her surroundings should be clean all the time. She can share her emotional feelings to anyone.

\section{Leisure activities}

She will watch TV in the free time. She will also involve in other activities like meditation.

\section{Medical care}

She will regularly consult the doctors who visit their place.

Since from 2 years she is staying in this old age home. Daughters visits regularly to see her and they will give money for personal use.

Different types of scales administered on her:

Ucla loneliness scale: Results interpreted that she is extreme range of lonliness.

Satisfaction with life scale: Showed that she only slight satisfaction towards her life.

Bradburn scale of psychological well - being: The study revealed that her psychological well being is mild.

\section{Elderly Motivation Scale: Results Revealed That She Has Very Less Motivation.}

\section{CONCLUSION}

She has done all responsibilities in her life. Based on these scales she is slightly satisfied and she is active. She feels loneliness because of away from their family members. She doesn't have any desires or wants. She is praying to god that she is ready for death.

\section{CASE STUDY 3}

PromilaAmma, 69 years: Old women, from Telangana, were living in the old age home from 10 years. She looked very cheerful and enthusiastic. She didn't have teeths but was very talkative. She came there on her own wish as she didn't have any other place to stay. After her marriage, her husband died within three years and she started to live with her sister and her family. Since she didn't have any children, her sister was the only support. But her sister's husband didn't like her staying in their home. So. In fear she left the house and came to stay in the old age home. Her sister pays her visit yearly or sometimes she goes to visit her. She doesn't have any regrets in her life and follows the Om shanti. Once she slipped in the bathroom and got injury on her head. She takes the medicine for the blood pressure. Physically she is capable of doing her all the work and also she is ready to work for others. She also goes for morning walk. She does little sewing work and cut vegetables daily. She was happy with her life and has no regrets. There was no sign of any disappointment for not having children. She was happy with what she has and her present life. 


\section{CASE STUDY 4}

Sarubai, 80 years: Old lady came to the old age home, on the very same day we visited there. She came there as someone told her about the old age home. She has no relative to stay with. She was a fair looking lady with no health issues. During her earlier times, she was a tailor. She was irritated due to continuous chatting of others. She was a spiritual lady and was not much socialized as she has different mother tongue, Marathi and believed that why to gossip, should work honestly and no need to interfere in other's work. She was highly satisfied with her life and had no regrets. She has visited quite a many religious places.

After the interaction with the two different women it was so very obvious that they are adjusting to their life here, mentally strong as they don’t blame for anything they have accepted what life has given them. Physically if observed not all but few were quite active in participating in their work in cooking, cutting and washing seems to be the normal work been done by them.

\section{CASE STUDY 5}

Shashartna 80 years : This primary educated old lady hailed from Vanasthalipuram .At the age of 12 she got married and after 3 years of marriage her husband was expired. Her in laws didn't supported her and her brother brought her to the city and she started working as a maid for few years and then she worked as a caretaker of a baby. She did all rearing and caring of that baby and used to stay in their home only. She never contacted any of the her family member. When child had grown up his parents brought lady to the old age home i.e. 20 years back and from then she is staying in that home.

Physical appearance: Lean body with grey hair, no teeth, weak eyesight but glow in face. With bending back wrinkled skin with a look of skin wrapped to skeleton she can do her routine work

Satisfaction with life cycle scale: Score obtained by her after administering this scale reveal that ,which falls under the satisfied category. It can be interpreted that her life span was close to her ideal and her conditions were good enough. And she did not want any change in her life.

Subjective happiness scale: As per the scale respondent was quite happier and considered herself happier, content and enjoyed the life regardless of what is going on. She was not at all depressed and tried to make her surroundings happy by her presence.

Cognitive assessment scale for elderly: Temporal orientation was excellent. She was able to remember her date of birth, age, year of birth, time. Under Spatial orientation she was able to state the place of birth, directions to go for dining hall, temple. Attention concentration and calculation she identified the numbers but confused with symbols and did simple calculations. Immediate recall ; identified the items and recalled the resemblance of item.

She was well versed only in telugu language but having problem in speaking because of dental decay. Remote memory; her past long term memory was good remembered all information about 
her parents. Judgement and abstraction skills were good and abstract was more prominent and judgement taken time to process. Recent memory was not good and seemed very difficult to recall the recent things.

\section{Elderly motivation scale}

- Health and biological activities: She used to follow her daily activities like bathing, washing clothes, walking, and eating, proper sleep and wanted to do it for her own good to remain active.

- Relationship with others: She was having good relationship with people who were staying there and she liked to make friends.

- Religion: She was very spiritual, spent her time in chanting hymns, reading spiritual books because she found pleasure in doing it.

- Leisure: Used to do leisure activities for her own pleasure.

- Information: She did not follow news.

\section{Geriatric depression scale}

- Her scores stated that she not under depression, she was normal and satisfied with her life.

\section{UCLA loneliness scale}

- Her score for this scale was 6 which means she was normal, do not feel lonely and left out. Though sometime she felt to meet family and that child. She was helping and caring for others also.

\section{Conclusion}

- Respondent was happy, active, social, and calm and satisfied in her life.

- She was spiritual and member of brahmakumari organization.

- Her cognitive skills were declined but emotionally she has shown well stable and controlled behaviour. Physically she was active comparatively other members, she used to perform all her daily chores by herself but strength has been reduced.

- She was having positive outlook and affect of her life though in younger stages she suffered but she did not surrender herself and did not lose hope of living.

- She said whatever challenges may come in life don't lose hope, have faith in God and face it.

\section{CASE STUDY 6}

Sarubai80 years (old old): Belongs to Pochammagudi, Hyderabad, basically Marathi

She is short height, fair in complexion, good physical conditions. Eye operation has been done. 
She has been living in the old age home since three months. She ran away from her home and her children don’t know about her whereabouts. She has 3 sons and 3 daughters. She is a spiritual lady. In free time she write god's name in one notebook repeatedly. She has visited quite a many religious places including Haridwar, Rameshwaram. She was happy living in the old age home.

Satisfaction with life scale: According to the scale administered, the responder got a score indicates that she is satisfied with her life.

Subjective happiness scale: It is designed to measure the subjective happiness. According to the scores obtained, she was found to be happy.

Ucla loneliness scale: It was used to administer one's subjective feelings of loneliness as well as feelings of social isolation. The score indicate mild level of loneliness or social isolation

\section{CASE: Cognitive Assessment Scale for Elderly}

- Temporal orientation: the responder was able to memorize the year of birth as well as her age. Moreover she was able to tell about some landmarks for eg, age at the time of Gandhi ji's death.

- Spatial orientation: the responder was well known with respect to the spatial orientation as she had visited many places on her own. She was able to memorize the basic addresses and some landmarks.

- Attention concentration and calculation: the responder was able to identify the numbers, had confusion in identifying 6 and 9. But she was not able to carry out the calculations.

- Immediate recall: after showing some basic designs, she was able to relate them in our nearby surroundings.

- Language: she had a good grip on the language. She spoke fluently without any hindrance.

- Remote memory: the responder was able to memorize all the facts related to her family members like mother, father, their name, occupation etc

\section{Elderly motivation scale:}

- It was administered to look at the personal attitude towards 6 different life domains: health, biological needs, relations with others, religion, leisure and information

- Health activities: as responded, the responder does the health activities and keeps up with the diet for the pleasure of doing it.

- Biological needs: the activities are done because they are supposed to be done.

- Relationship with others: don't keep relations with others.

- Religion: done for the pleasure of doing it.

- Leisure: she thinks that these activities are supposed to be done. 
Geriatric depression scale: According to the scores obtained the responder is not in a depression state and is no longer close to it.

\section{CASE STUDY 7}

Lakshmi80 years: She was staying in old age home since 5 years. She has only one child she got her marriage. Since no one is there to take care of her after her daughter's marriage so she comes to old age home.

\section{Physical development}

\begin{tabular}{|c|c|c|}
\hline Vision & Hearing & smell \\
\hline $\begin{array}{l}\text { She is having good vision. } \\
\text { She can able to do embroidery } \\
\text { stitches by her own. }\end{array}$ & $\begin{array}{l}\text { She cannot here or difficulty } \\
\text { in hearing. When we will } \\
\text { impose the question she never } \\
\text { replies. If we speak louder } \\
\text { than only she can able to here } \\
\text { and then she ask for direction }\end{array}$ & $\begin{array}{l}\text { She has a problem in sensing } \\
\text { the smell. }\end{array}$ \\
\hline Touch & Taste & \\
\hline $\begin{array}{l}\text { She can easily feel pain when } \\
\text { she will walk on the rough } \\
\text { area. } \\
\text { She can easily identify objects } \\
\text { through touch. }\end{array}$ & $\begin{array}{l}\text { She never eats spicy food } \\
\text { mostly prefer easily digestible } \\
\text { food which is healthy and } \\
\text { tasty. } \\
\text { She likes to eat sweets, }\end{array}$ & \\
\hline
\end{tabular}

Cognitive development: She has good memory. She can easily remember the places of objectives where she has placed before. Actively participate in all kind of works especially in washing clothes, vegetable cutting, cooking, filling water in a buckets for her personal use. She can keep her cupboard very neatly and she will try to make her surroundings should be clean all the time. A very emotional person didn’t like to share her emotions with anyone.

\section{LEISURE ACTIVITIES: MEDITATION AND WALKING}

Medical care: She will regularly consult the doctor who visits the place.She will be very much conscious about her health.

\section{CONCLUSION}

According to the three scales results laxmi is happily staying in the old age home and she very much satisfied with the facilities' available in the home. 


\section{CASE STUDY 8}

Kanthamma91years:A primary educated old women from Chennai . Born in year 1922 born and she recently lost her husband. Wrinkled skin, grey hair with decreased bone density but is at good health condition. Movement is good

Psychological well being: Can remember names, only mild memory loss can be seen, happy, cheerful, calm. Anger gets easily when someone does not respond to her question. And has love for very one with expressive emotions. Shows depression when she thinks about her younger son who is not well settled in the life,

Social well being: Gets well along with the individual and likes to spend time with the grand children.

\section{Physical development}

\begin{tabular}{|l|l|l|}
\hline Vision & Hearing & Smell \\
\hline $\begin{array}{l}\text { Good vision but sometimes } \\
\text { arrested with games. }\end{array}$ & $\begin{array}{l}\text { Hearing loss can be seen can } \\
\text { not listen when we spoke } \\
\text { slowly }\end{array}$ & $\begin{array}{l}\text { She doesn't have any problem } \\
\text { in sensing the smell. }\end{array}$ \\
\hline Touch & Taste & Mobility strength \\
\hline touch is good & $\begin{array}{l}\text { She eats all type of food can feel pain in feet areas } \\
\text { Food which is healthy and } \\
\text { tasty. And the ones witch is } \\
\text { spicier also. }\end{array}$ & $\begin{array}{l}\text { High can climb stairs with } \\
\text { outhelp can walk long } \\
\text { distances. }\end{array}$ \\
\hline
\end{tabular}

Cognitive development: She has good memory capacity

Vision loss is seen in mild form although memories, language, processicing, are at normal level, ageing has an impact on it.

Medical care: Weakness of heart is seen. She was under regular homeopathy medicines for her never weakness and heart problem.

Recreational activities: Meditation on regular basis, play with grand children can be seen.

The daily living activities: Cooking, folding cloths, washing vessels, cleaning floor is required, drying clothes, arranging kitchen, taking care of grand children, self help skills are normal. 


\section{Over all arrangements interms of biological theories}

Stress theory: As she is actively involved in life activities and social activities she is likely to be affected by stress.

\section{Socio emotional theory}

Erikson's theory: When seen with the past and present she was happy at e ach event expressing integrity of son's settlement expressing despaired.

Activity theory: Active involvement in social activities and getting along with relations had on positive impact on life.

\section{CONCLUSION}

Recently India is witnessing rapid growth of older population. Disintegration of the joint family system and the impact of economic change have brought into sharp focus the peculiar problems which the old people now face in our country. And in the traditional sense, the duty and obligation of the younger generation towards the older generation is being eroded. The older generation is caught between the decline in traditional values on one hand and the absence of an adequate social security system on the other hand thus, finding it difficult to adjust in the family. The study reveals that the most of the women life satisfaction, lonliness and depression is present. And other important feature is that though most of respondents are in their 80s they were able to complete their routine activities without much difficulty.

\section{REFERENCES}

Arber S, Ginn J. Gender and later life. Sage, London: 1991.

Beck A. T, Ward C. H, Mendelson M, Mock J, Erbaugh J. An inventory for measuring depression. Archives of General Psychiatry. 1961;4:561-571.

Borchelt M, Gilberg R, Horgas A. I, Geiselmann B. On the significance of morbidity and disability in old age. In: Baltes P.B, Mayer K.U, editors. The Berlin Aging Study: Aging from 70 to 100. New York: Cambridge University Press; 1999. pp. 403-429.

Bruce M. L, Seeman T, Merrill S. S, Blazer D. G. The impact of depressive symptomatology on physical disability: MacArthur Studies of successful aging. American Journal of Public Health. 1994;84:1796-1799.

Charles S. T, Reynolds C. A, Gatz M. Age-related differences and change in positive and negative affect over 23 years. Journal of Personality and Social Psychology. 2001;80:136-151. [

Costa P. T, Jr, McCrea R. R. Influence of extra version and neuroticism on subjective wellbeing: Happy and Unhappy people. Journal of Personality and Social Psychology. 1980;38:668-678.

Rowe J. W, Khan R. L. Human aging: Usual and successful. Science. 1987;237:143-149.

Warnick J. Listening with different ears: Counseling people over sixty. Ft. Bragg CA: QED Press; 1995 